\title{
Effects of Internal Factors on Financial Performance of Joint Venture Banks in Nepal
}

\author{
Deepesh Ranabhat*
}

\begin{abstract}
This paper examines the impact of bank specific variables on financial performance of joint venture banks. The return on assets and return on equity are selected as bank's performance variables for this study and these two are the dependent variables. Spread rate, size of assets, loan, deposit, liquidity and capital adequacy ratio of the firms are the independent variables. The data are collected from supervision report of Nepal Rastra Bank and annual reports of concerned six banks for 10 years from fiscal year 2008/09 to 2017/18. The pooled OLS multiple regression models are applied to test the significance and effects of bank specific variable on financial performance of Nepalese Joint Venture Banks. The result shows that there is a significant positive impact of interest rate spread on ROA and ROE of the banks. Similarly, there is significant negative impact of asset size on ROA and significant negative impact of liquidity and loan ratio on ROE of the banks.
\end{abstract}

Keywords: Capital adequacy, liquidity, return on assets, return on equity.

\section{INTRODUCTION}

Commercial banks play a major role in the economy through their economic role of financial intermediation that performs both a brokerage and a risk transformation function (Hara, 1983). Commercial banks are financial intermediaries that mobilize savings from surplus economic units to deficit economic units. How well they perform this intermediary function has direct linkage with banks profitability and economic health of a nation. Profitability of banks has relationships with growth and development of an economy (Wainaina, 2013). After the liberalization in the mid-1980s, the government permitted the opening of commercial banks in joint venture with foreign banks. Since then, the Nepalese financial system has undergone rapid structural changes, with a large number of financial institutions expose and display of financial products and services (Baral, 2005).

Financial ratios can be grouped into five broad categories namely; liquidity, leverage, turnover, profitability and valuation ratios. Profitability ratios consist of tests used to evaluate a firms earning performance. The major types of profitability ratios are calculated in relation to sales and investments. Profitability in relation to sales ratios includes; gross profit margin, net profit margin, contribution ratio, operating expenses ratio while profitability in relation to investments includes; return on investments (ROI), return on equity (ROE) and return on total assets (ROA).

The performance of commercial banks can be affected by internal and external factors (Hassan Al-Tamimi, 2010). These factors can be classified into bank specific (internal) and macroeconomic variables. The internal factors are individual bank characteristics which affect the bank's performance. These factors are basically influenced by the internal decisions of management and board. The external

\footnotetext{
* Mr. Ranabhat is Lecturer in School of Business, Pokhara University.

Email: deepeshrana2000@gmail.com
} 
factors are sector wide or country wide factors which are beyond the control of the company and affect the profitability of banks (Ongore, 2011).

Several studies have examined the linkage between bank specific variable on financial performance in different parts of the world. Gilchris (2013) examined the influence of bank specific factors on samples of 25 commercial banks profitability from 2007 to 2011 in Pakistan. The regression results indicated that bank size, net interest margin, and industry production growth rate had positive and significant impact on the profitability (return on asset and return on equity). Capital ratio has positive significant impact on ROE. Buyinza, Francois, and Landesmann (2010) investigated samples of 23 commercial banks profitability from 1999 to 2006 in Sub Sahara Africa countries. The study utilized panel data and the regression results revealed that capital, efficient expenses management, bank size, credit risk, diversified earning ability of the banks, per capital GDP, growth rate and inflation have significant and positive impact on banks' profitability. To maximize the financial performance is a set of activities where the interest rate, size or total assets, loan, liquidity, deposits, and capital are taken under consideration. So, this study aims to analyze the effect of bank specific (internal) variables with financial performance of joint venture banks in Nepal.

\section{LITERATURE REVIEW}

Factors affecting financial performance of bank has given wide attention. Broadly these factors can be classified as internal factors and external factors. The internal factors are individual bank characteristics which affect the bank's performance and are basically influenced by the internal decisions of management and board. Internal factors includes interest rate spread, loan, deposit, capital, asset size, liquidity etc. Different theories and past studies has shown different relationship between internal factors and financial performance of banks. Interest spread is difference between interest earned and interest paid. It is the net income received by the banks. So there is positive relationship between interest spread and profitability of banks. However high interest rate on loan discourage the borrower while low interest rate on deposit discourage the depositor which ultimately decrease the performance of bank. Molyneux and Thornton (1992) find a positive relationship between the ratios of spread interest rate and bank profitability in Russia. Similarly, Demsetz (1983) showed positive relationship between spread interest rate and firm performance.

Similarly, there are different views regarding the size and performance. Size is included to assess the existence of economies or diseconomies of scale in the banking sector. Large size helps to decrease cost as there is existence of economies of scale and increase profitability. However, increase in size leads to operational inefficiencies and thereby decrease profitability. Fadzlan and Kahazanah (2009) find a positive and significant relationship between size and bank performance. Demirguc and Huizingua (1999) find a negative relationship between the size of the banking sector and profitability measures that reflects the higher level of competition in developed banking sector. Berger et al., (1987), provide evidence that costs are reduced only slightly by increasing the size of a bank and that very large bank often encounter scale inefficiencies. The empirical results provide conflicting evidence.

In the same manner, current assets investment policy argues that there is negative relationship between liquidity and financial performance as current assets are unproductive or less productive asset high investment in current asset decreases the ROA and ROE. Naceur and Omran (2010) find negative relationship between liquidity and performance. Deposit is the only initial source of the bank for 
investment. Regarding the relationship between deposit and bank financial performance two arguments can be opposed on the one hand, a high level of deposits can increase performance, because deposits are more stable funding and less expensive than borrowed funds, but on the other hand, such deposits require large teams and specialist departments to manage, causing many expenses. Kunt and Huizinga (1999) results support the second argument that the high costs generated by these deposits lead to weigh negatively on the performance of banks. Loan is the major source of income for the banks. It has significant impact on the performance of the banking sector. Interest charged on loan by the banks is always higher than the interest paid on deposit so higher loan ratio results in higher profitability of banks. However, if the ratio of loan to total assets is high then the risk of default the credit is also higher. Miller and Noulas (1997) found negative relationship between credit and profitability because a higher loan to asset ratio increases the exposure of banks to bad loans and hence lowers profit margins.

The traditional view suggests a higher capital-asset ratio (CAR) is linked with a lower return on equity (ROE) because a higher CAR decreases the risk on equity and the tax subsidy provided by interest deductibility. Berger (1995) found that a strong positive relationship between capital and earnings, meaning well capitalized firms face lower expected bankruptcy costs, which in turn reduce their cost of funding and increase their profitability. Ponce (2013) finds a positive relationship between bank performance and capitalization.

Similarly, Rachdi (2013) indicate that, before the US subprime crisis, capital adequacy, liquidity, bank size and yearly real GDP growth affect positively the performance (ROA, ROE and NIM) of Banks. In crisis period, bank profitability is mainly explained by operational efficiency, yearly growth of deposits, GDP growth and inflation. Khrawish, and Siam, (2011) show capital, bank size, financial risk, GDP growth rate, inflation, and exchange rate have significant negative relationship with profitability but interest has insignificant positive relationship with the profitability of Islamic banks in Jordan.

Various empirical studies have been made in context of developed and developing economies. However, the results are mixed and it still needs further examination. So this study has examined the effect of interest rate spread, firm size, deposit, lending, liquidity and capital on financial performance of Nepalese joint venture banks.

\section{CONCEPTUAL FRAMEWORK}

The conceptual framework considered for this study is as follows.

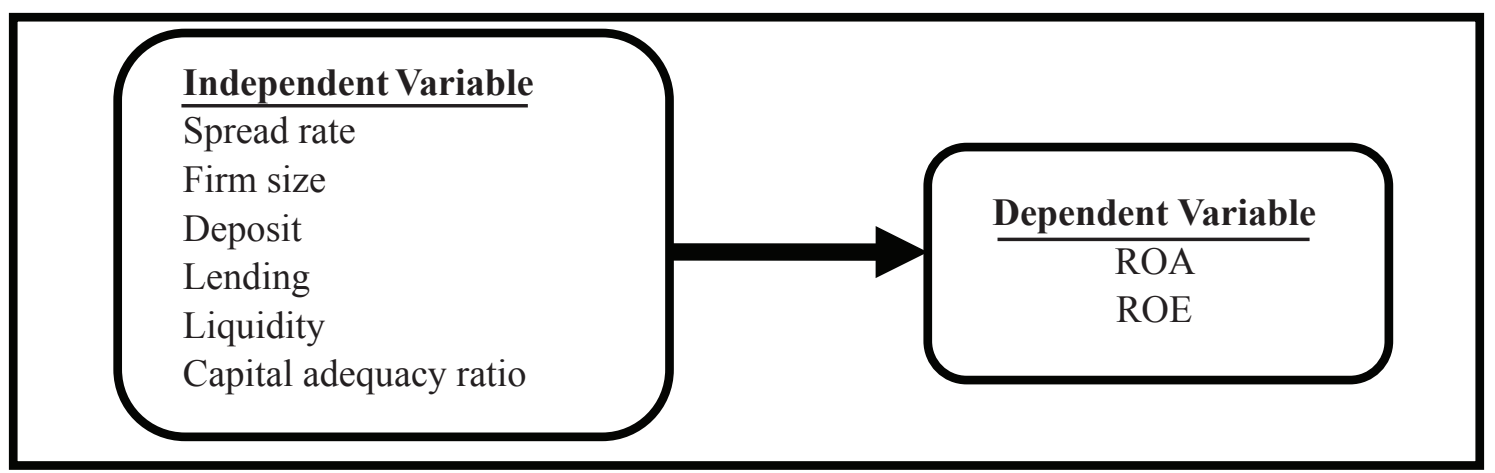

Figure 1. Conceptual framework. 
This study examines the relationship of spread rate, firm size, liquidity, deposit and capital adequacy ratios on ROE and ROA. The operational definitions for all the variables used in this study are as follows:

Interest rate spread: Interest rates spread is defined as the difference between weighted average interest rate earned on interest earning assets (loans) and weighted average interest rate paid on deposits (from savers).

Firm Size: Firm size is defined as the natural logarithm of the total assets at the end of period. Size is the dominant factor seen to influence the performance and risk of the banking industry.

Loans: It refers to the ratio of loan to total assets. Loan is the major source of income for the banks. It has significant impact on the performance of the banking sector.

Deposit: It refers to the ratio of total deposits to the total assets. If this ratio is higher, it is termed as the bank is more liquid. However, it also shows that the liability of the organization is also higher.

Liquidity: It refers to the ratio of liquid fund to total assets. It shows how sound is the bank in terms of makings their payments. Higher liquidity ratio indicates less risk to the organization. It also states that the profitability of the organization will be lower if this ratio is higher.

Capital adequacy ratio (CAR): The capital adequacy ratio (CAR) refers to ratio of a bank's available capital and bank's risk-weighted credit exposures. The capital adequacy ratio, also known as capital-torisk weighted assets ratio (CRAR), is used to protect depositors and promote the stability and efficiency of financial systems around the world. A high ratio indicates lower risk.

Return on assets (ROA): ROA is the ratio of net income after tax to the total assets of the bank. It is an indicator of how profitable a company is before leverage, and is compared with companies in the same industry. It reflects the company's ability to convert assets to generate profits.

Return on equity (ROE): ROE is the ratio of net income after tax to the total equity of the bank. The ROE shows the extent to which a bank is successful to mobilize its equity. It is measuring rod of the profitability. A high ratio indicates the success of bank in mobilizing its equity capital and vice-versa.

\section{DATA AND METHODS}

The pooled cross-sectional data analysis has been undertaken in the study. The research adopted causal comparative research to determine the effect of interest spread rate, bank firm size, loan, liquidity, deposit and capital on performance of joint venture banks in Nepal. The study is based on the secondary data which were gathered for six joint venture banks in Nepal which were in operation before 2060 B.S. (i.e. Nabil bank, Standard Chartered bank, Himalayan bank, Nepal Bangladesh bank, Nepal SBI bank and Everest bank). The main sources of data are supervision report of Nepal Rastra Bank and annual reports of selected banks. The data were collected on ROA, ROE, spread rate, assets size, loans, liquidity, deposit and capital of selected commercial banks for the period 2008/09 to 2017/18. 
Descriptive statistics such as mean, standard deviation minimum and maximum values have been used to describe the characteristics of bank performance and factors affecting it during the period. Correlation analysis has been adopted to identify the direction and magnitude of relationship between different pairs of variables and regression analysis has been used to analyze the relationship between dependent variable and independent variables. For reliability and validity of the study only published data are used for analysis and different assumptions of OLS has been tested before using the pooled OLS regression models. Correlation matrix and variance inflation factor (VIP) are used to check the multicolinearity among independent variables. Likewise, Cook's distance statistics is used to identify outliers and Durbin Watsons statistics is used to check the autocorrelation in the residuals.

Table 1 shows the sample banks selected for the study along with the study period and number of observations.

Table 1

Sample Banks Selected for the Study

\begin{tabular}{clrc}
\hline S. No. & Name of commercial banks & Study period & Observations \\
\hline 1. & Standard Chartered Bank Ltd. & $2008 / 09-2017 / 18$ & 10 \\
2. & Nabil Bank Ltd. & $2008 / 09-2017 / 18$ & 10 \\
3. & Everest Bank Ltd & $2008 / 09-2017 / 18$ & 10 \\
4. & Nepal SBI Bank Ltd. & $2008 / 09-2017 / 18$ & 10 \\
5. & Himalayan Bank Ltd. & $2008 / 09-2017 / 18$ & 10 \\
6. & Nepal Bangladesh Bank Ltd. & $2008 / 09-2017 / 18$ & 10 \\
\hline & & 60 \\
\hline
\end{tabular}

\section{Model Specification}

In this study pooled OLS multiple regression model is used to analyze the relationship between dependent variables and independent variables. The dependent variables for this study are return on assets (ROA) and return on equity (ROE). Spread rate, size of assets, loan, deposit, liquidity and capital adequacy ratio (CAR) of the firms are the independent variables. The multiple regression models used in this study are;

Model 1: ROA is dependent variable and internal factors are independent variables

The model is, ROA $=\beta_{0}+\beta_{I} S R+\beta_{2}$ Size $+\beta_{3}$ Loans $+\beta_{4}$ Deposit $+\beta_{5}$ Liquidity $+\beta_{6}$ CAR $+e$.

Model 2: ROE is dependent variable and internal factors are independent variables

The model is, $R O E=\beta_{0}+\beta_{1} S R+\beta_{2}$ Size $+\beta_{3}$ Loans $+\beta_{4}$ Deposit $+\beta_{5}$ Liquidity $+\beta_{6} C A R+e$.

\subsection{Descriptive Statistics}

\section{RESULTS AND DISCUSSION}

The descriptive statistic includes minimum value, maximum value, mean value and standard deviation. Table 2 presents the descriptive statistics of dependent and independent variables for total sample of this study. 
Table 2

Descriptive Statistics of Variables

\begin{tabular}{lrrrrr}
\hline Variables & N & Minimum & Maximum & Mean & Std. deviation \\
\hline Spread rate & 60 & 2.70 & 8.09 & 4.47 & 0.93 \\
Size(Rs in billion) & 60 & 11.97 & 160.98 & 66.01 & 34.08 \\
Loan & 60 & 33.71 & 73.98 & 59.54 & 9.47 \\
Deposit & 60 & 76.94 & 92.03 & 85.97 & 3.55 \\
Liquidity & 60 & 6.16 & 41.33 & 17.95 & 8.35 \\
CAR & 60 & 5.55 & 23.68 & 12.73 & 2.64 \\
ROA & 60 & 0.83 & 18.04 & 2.46 & 2.30 \\
ROE & 60 & 9.75 & 47.87 & 22.56 & 6.98 \\
\hline
\end{tabular}

Table 2 shows the descriptive statistics of dependent and independent variables used in the study. The range of ROA is 17.21 percent withan average of 2.49 and standard deviation of 2.30 and the range of ROE is 38.12 percent with an average of 22.56 and standard deviation of 6.98 . It is clear that there is huge difference in profitabilityamong different joint ventures banks in Nepal during the study period.

Similarly, the mean of weighted average spread rate 4.47 percent denotes that the difference between interest rate earned on loans and interest rate paid on deposits by joint venture banks in Nepal is 4.47 percent during the study period, however, it range from. 2.7 percent to 8.09 percent among different banks during different periods. The assets size has a range of Rs.149.01 billion and mean of Rs.66.01 billion. It reveals that the average assets size of joint venture banks in Nepal during the study period is Rs.66.01 billion. Likewise, on average the loan to assets ratio of the banks is 59.54 percent, average of deposit to total asset is 85.97 percent, average liquid assets out of total assets is 17.95 percent and average capital adequacy ratio of joint venture bank is 12.73 percent during the study period.

\subsection{Correlation Analysis}

The Pearson Correlation Coefficients have been computed and the results are presented in Table 3 . All the correlations between independent variables can be considered as low. This indicates that there is no multicolinearity exists among the independent variables.

The result indicates that ROA is positively related spread rate, liquidity and capital adequacy ratio and negatively related to asset size, deposit and loan ratio. Likewise, it also reveals that ROE is positively related to spread rate, capital adequacy ratio and negatively related to asset size, deposit, liquidity and loan ratio. 
Table 3

Correlation Matrix for the Dependent and Independent Variables

\begin{tabular}{|c|c|c|c|c|c|c|c|c|c|}
\hline Variables & & SR & Size & Deposit & Liquidity & CAR & Loan & $\mathrm{ROA}$ & ROE \\
\hline SR & $\begin{array}{l}\text { Pearson's r } \\
\text { p-value }\end{array}$ & - & & & & & & & \\
\hline Size & $\begin{array}{l}\text { Pearson's r } \\
\text { p-value }\end{array}$ & $\begin{array}{l}-0.17 \\
0.204\end{array}$ & - & & & & & & \\
\hline Deposit & $\begin{array}{l}\text { Pearson's r } \\
\text { p-value }\end{array}$ & $\begin{array}{l}0.05 \\
0.705\end{array}$ & $\begin{array}{l}0.088 \\
0.504\end{array}$ & - & & & & & \\
\hline Liquidity & $\begin{array}{l}\text { Pearson's r } \\
\text { p-value }\end{array}$ & $\begin{array}{l}0.363 \\
0.004\end{array}$ & $\begin{array}{l}0.134 \\
0.307\end{array}$ & $\begin{array}{l}0.449 \\
<.001\end{array}$ & - & & & & \\
\hline CAR & $\begin{array}{l}\text { Pearson's r } \\
\text { p-value }\end{array}$ & $\begin{array}{l}-0.04 \\
0.776\end{array}$ & $\begin{array}{l}-0.43 \\
<.001\end{array}$ & $\begin{array}{l}-0.027 \\
0.839\end{array}$ & $\begin{array}{l}-0.157 \\
0.232\end{array}$ & - & & & \\
\hline Loan & $\begin{array}{l}\text { Pearson's r } \\
\text { p-value }\end{array}$ & $\begin{array}{l}0.234 \\
0.072\end{array}$ & $\begin{array}{l}0.294 \\
0.023\end{array}$ & $\begin{array}{l}-0.27 \\
0.037\end{array}$ & $\begin{array}{l}-0.142 \\
0.28\end{array}$ & $\begin{array}{l}-0.1 \\
0.468\end{array}$ & - & & \\
\hline ROA & $\begin{array}{l}\text { Pearson's r } \\
\text { p-value }\end{array}$ & $\begin{array}{l}0.596 \\
<.001\end{array}$ & $\begin{array}{l}-0.42 \\
<.001\end{array}$ & $\begin{array}{l}-0.069 \\
0.602\end{array}$ & $\begin{array}{l}0.098 \\
0.456\end{array}$ & $\begin{array}{l}0.244 \\
0.06\end{array}$ & $\begin{array}{l}-0.03 \\
0.813\end{array}$ & - & \\
\hline ROE & $\begin{array}{l}\text { Pearson's r } \\
\text { p-value }\end{array}$ & $\begin{array}{l}0.542 \\
<.001\end{array}$ & $\begin{array}{l}-0.39 \\
0.002\end{array}$ & $\begin{array}{l}-0.089 \\
0.498\end{array}$ & $\begin{array}{l}-0.017 \\
0.896\end{array}$ & $\begin{array}{l}0.235 \\
0.07\end{array}$ & $\begin{array}{l}-0.09 \\
0.493\end{array}$ & $\begin{array}{l}0.951 \\
<.001\end{array}$ & - \\
\hline
\end{tabular}

\subsection{Regression Analysis}

The regression of bank specific variables such as spread rate, size of assets, loan ratio, deposit ratio, liquidity and capital adqequacy on bank performance has been analysed by defining bank performance in terms of ROA and ROE.

Regression of Bank Specific Variables on ROA

The results are based on pooled cross-sectional data of 6 banks with 60 observations for the period 2008/09-2017/18 by using pooled OLS multiple regression model. The model is, $\mathrm{ROA}=\beta_{0}+\beta_{1} \mathrm{SR}+$ $\beta_{2}$ Size $+\beta_{3}$ Loans $+\beta_{4}$ Deposit $+\beta_{5}$ Liquidity $+\beta_{6}$ CAR + e.

Table 4

Model Fit Measures

\begin{tabular}{llllllll}
\hline \multirow{2}{*}{ Model } & \multirow{2}{*}{ Adjusted R } & \multirow{2}{*}{ AIC } & BIC & \multicolumn{4}{c}{ Overall model test } \\
\cline { 5 - 8 } & & & & F & df1 & df2 & $p$ \\
\hline 1 & 0.444 & 245 & 261 & 8.84 & 6 & 53 & $<.001$ \\
3 & 0.439 & 243 & 256 & 12.5 & 4 & 55 & $<.001$ \\
\hline
\end{tabular}


Table 5

\section{Model Coefficients-ROA}

\begin{tabular}{rlrrrr}
\hline Model & Predictor & Estimate & SE & $\mathrm{t}$ & $\mathrm{p}$ \\
\hline \multirow{6}{*}{1} & Intercept & 7.45776 & 5.4928 & 1.358 & 0.18 \\
& SR & 1.5606 & 0.2944 & 5.302 & $<.001$ \\
& Size & -0.78539 & 0.4994 & -1.573 & 0.122 \\
& Liquidity & -0.01624 & 0.0343 & -0.473 & 0.638 \\
& CAR & 0.0011 & $7.47 \mathrm{E}-04$ & 1.468 & 0.148 \\
& Loan & -0.03485 & 0.0294 & -1.187 & 0.241 \\
& Deposit & -0.0133 & 0.0167 & -0.798 & 0.429 \\
\hline \multirow{6}{*}{2} & Intercept & 11.6665 & 4.7922 & 2.434 & 0.018 \\
& SR & 1.4406 & 0.2616 & 5.507 & $<.001$ \\
& Size & -1.1579 & 0.4403 & -2.63 & 0.011 \\
& Loan & -0.0279 & 0.0286 & -0.975 & 0.334 \\
& Deposit & -0.0152 & 0.0155 & -0.981 & 0.331 \\
\hline \multirow{2}{*}{3} & Intercept & 11.24 & 4.701 & 2.39 & 0.02 \\
& SR & 1.34 & 0.244 & 5.5 & $<.001$ \\
& Size & -1.35 & 0.401 & -3.38 & 0.001 \\
\hline
\end{tabular}

Table 5 shows the coefficients of regression models of ROA.From the table beta coefficientsare negative for assets size, liquidity, loan and deposit which indicates that increase in assets size, liquidity, loan and deposit results decrease in ROA. However, the beta coefficients are not significant for liquidity, loan and deposit in the above models. But the beta coefficent for size is significant at 5 percent level of significance in model 2 and significant at 1 percent in model 3. Similalry, beta coefficients for spread rate and capital adequacy ratio are positive which indicate that increase in spread rate and capital adequacy ratio results increase in ROA as well and vice-versa. However, only the beta for spread rate is significant at 1 percnet level of significance in all models. So it can be concluded that spread rate and assets size are the major internal factors that affect ROA.

Table 4 presents the model fit mearures. From the table the p-value of F-statistc of all 3 models are less than 1 percent level of significance which indicates that all models presented here are good. However, the adjusted R2 of model 3 is higher, also the AIC and BIC of model 3 is less than the model 1 and 2 , so the best fitted model of ROA is model 3 . And the regression equation is;

$\mathrm{ROA}=11.24+1.34 \mathrm{SR}-1.35 \mathrm{Size}+\mathrm{e}$

Here the adjusted $\mathrm{R}^{2}$ is 0.444 which indicates that 44.4 percent variation in ROA is explained by spread rate and firm size and remaining 55.6 percent variation in ROA is explained by other factors.

Model diagnostics for ROA are given in Appendix A. Table A1 of Appendix A shows the Cook's distance value of different models used in ROA. The standard deviation of model 1, 2, and 3 is less than 1 which indicates that there is no significant outliers which have an influence on the regression. Similarly, Durbin-Watson test statistic is presented in Table A2 of Appendix A. The p-value of all 3 models is more than 1 percent. So at 1 percent level of significance we accept Ho, which denotes that the residuals are independent. Likewise, multicollinearity test statistics is presented in Table A3 of Appendix A. The VIF 
of all independent variables in all models is less than 5 and tolerance is more than 0.2 . It indicates that the independent variables are not correlated with each other. So all these statistics shows that the models of ROA are robustness.

\section{Regression of Bank Specific Variables on ROE}

The results are based on pooled cross-sectional data of 6 banks with 60 observations for the period 2008/09-2017/18 by using pooled OLS multiple regression model. The model is, $\mathrm{ROE}=\beta_{0}+\beta_{1} \mathrm{SR}+$ $\beta_{2}$ Size $+\beta_{3}$ Loans $+\beta_{4}$ Deposit $+\beta_{5}$ Liquidity $+\beta_{6}$ CAR + e.

Table 6

Model Fit Measures

\begin{tabular}{lcccccccc}
\hline \multirow{2}{*}{ Model } & \multirow{2}{*}{ Adjusted R } & \multirow{2}{*}{ AIC } & \multirow{2}{*}{ BIC } & \multicolumn{5}{c}{ Overall model test } \\
\cline { 5 - 8 } & & & $\mathrm{F}$ & $\mathrm{df1}$ & $\mathrm{df} 2$ & $\mathrm{p}$ \\
\hline 1 & 0.418 & 525 & 542 & 8.06 & 6 & 53 & $<.001$ \\
2 & 0.427 & 523 & 535 & 12 & 4 & 55 & $<.001$ \\
3 & 0.401 & 524 & 535 & 14.2 & 3 & 56 & $<.001$ \\
\hline
\end{tabular}

Table 7

Model Coefficients - ROE

\begin{tabular}{rlrrrr}
\hline Model & Predictor & Estimate & SE & $\mathrm{t}$ & $\mathrm{p}$ \\
\hline \multirow{6}{*}{1} & Intercept & 50.5782 & 57.0277 & 0.887 & 0.379 \\
& SR & 17.1684 & 3.05602 & 5.618 & $<.001$ \\
& Size & -3.8336 & 5.18499 & -0.739 & 0.463 \\
& Liquidity & -0.6459 & 0.35606 & -1.814 & 0.075 \\
& CAR & 0.011 & 0.00776 & 1.419 & 0.162 \\
& Deposit & -0.1173 & 0.17308 & -0.678 & 0.501 \\
& Loan & -0.6644 & 0.30486 & -2.179 & 0.034 \\
\hline \multirow{6}{*}{2} & -0.429 & 17.8509 & -0.024 & 0.981 \\
& Intercept & 18.1596 & 2.80926 & 6.4642 & $<.001$ \\
& SR & -0.8146 & 0.31322 & -2.6008 & 0.012 \\
& Liquidity & -0.7174 & 0.26887 & -2.668 & 0.01 \\
& Loan & 0.0132 & 0.00701 & 1.8882 & 0.064 \\
\hline & CAR & 5.682 & 17.953 & 0.317 & 0.753 \\
& Intercept & 18.488 & 2.867 & 6.448 & $<.001$ \\
& SR & -0.923 & 0.315 & -2.93 & 0.005 \\
& Liquidity & -0.785 & 0.272 & -2.881 & 0.006 \\
\hline & Loan & & & &
\end{tabular}

Table 7 shows the coefficients of regression models of ROE. From the table beta coefficients are positive for spread rate and capital adequacy ratio that indicates that increase in spread rate and capital adequacy ratio also increase ROE. However beta coefficient of CAR is not significant in both models 1 and 2. Similarly, beta coefficients are negative for assets size, liquidity, loan and deposit which indicates 
that increase in assets size, liquidity, loan and deposit results decrease in ROE. However, the beta coefficients are not significant for assets size and deposit in the model 1 and in other models they are not used. The beta coefficent for loan is significant at 5 percent level of significance in allmodels and the beta coefficient of liquidity is also significant at 5 percent level of significance in model 2 and 3 . So it can be concluded that spread rate, liquidity and loan ratio are the major internal factors that affect ROE.

Table 6 presents the model fit mearures. From the table the p-value of F-statistc of all 3 models are less than 1 percent level of significance which indicates that all models presented here are good. However, the adjusted $\mathrm{R}^{2}$ of model 2 is higher, also the AIC and BIC of model 2 is less than the model 1 and 3, so the best fitted model of ROE is model 2. And the regression equation is;

$\mathrm{ROE}=-0.429+18.16 \mathrm{SR}-0.8146$ Liquidity -0.7174 Loan $+0.0132 \mathrm{CAR}+\mathrm{e}$

Here the adjusted $\mathrm{R}^{2}$ is 0.427 which indicates that 42.7 percent variation in ROA is explained by spread rate, liquidity, loan and capital adequacy ratio and remaining 57.3 percent variation in ROE is explained by other factors.

Model diagnostics for ROE are given in Appendix B. Table B1 of Appendix B shows the Cook's distance value of different models used in ROE. The standard deviation of model 1,2, and 3 is less than 1 which indicates that there are no significant outliers which have an influence on the regression. Similarly, Durbin-Watson test statistic is presented in Table B2 of Appendix B. The p-value of all 3 models is more than 5 percent. So at 5 percent level of significance we accept Ho, which denotes that the residuals are independent. Likewise, multicollinearity test statistics is presented in Table B3 of Appendix B. The VIF of all independent variables in all models is less than 5 and tolerance is more than 0.2. It indicates that there is no correlation among independent variables. So all these statistics shows that the models of ROE are robustness.

\section{CONCLUSION}

Financial performance of banks can be measured in terms of ROA and ROE. Different internal factors may affect the performance of banks. From this study, it can be concluded that spread rate and assets size are the major internal factors that affect ROA. Where spread rate has a positive effect on ROA and assets size has negative effect on ROA of joint venture banks in Nepal. Similarly, it can be concluded that spread rate, liquidity and loan ratio are the significant internal factors that affect ROE. Where spread rate has a positive effect and liquidity and loan ratio has negative effect on ROE.

Joint venture banks in Nepal can make variation on profitability by changing spread rate, assets size, liquidity and loan ratio. In order to increase profitability banks should be able to raise spread rate while banks have to decrease assets size, liquidity and loan ratio to increase profitability.

In this study only joint venture banks are taken as sample and study period is taken for 10 years period. Likewise, external factors such as inflation, share price, GDP etc. are not considered, only internal factors are taken into consideration.

Similar kind of study can be done by taking more pooled cross sectional data and by including other commercial banks as well in sample. Likewise, further research can be done by including both internal and external factors for more valid results.

\section{REFERENCES}

Baral, K. J. (2005). Health checkup of commercial bank in framework of CAMEL: A case study of joint venture bank in Nepal. The Journal of Nepalese Business Studies, 2 (1), 41-55.

Berger, A. (1995). Problem loans and cost efficiency in commercial banks, economics and policy analysis. Working 
paper, 95.

Bourke, P. (1989). Concentration and other determinants of bank profitability in Europe, North America and Australia. Journal of Banking and Finance, 13(1), 65-79.

Buyinza, F., Francois, J., \& Landesmann, M. (2010). Determinants of profitability of commercial banks in Sub Saharan Africa Countries. Unpublished Work of the Department of Economics, Johanassen Keppler University, Linz-Austria.

Demirguc-Kunt, A., \& Huizinga, H. (1999). Determinants of commercial bank interest margins and profitability: Some international evidence. The World Bank Economic Review, 13(2), 379-408.

Demsetz, H. (1983). The structure of ownership and the theory of the firm. Journal of Law and Economics, 26 (2), 375-390.

Fadzlan, S., \& Kahazanah, F. (2009). Determinants of bank profitability in a developing economy: Empirical evidence from the China banking sector. Journal of Asia-Pacific Business, 10(4), 201-307.

Gilchris, M. (2013). Influence of bank specific and macroeconomic factors on the profitability of Commercial Banks in Pakistan during the time Period 2007 -2011. American Journal of Business and Finance.

Hara, M. (1983). A dynamic theory of the banking firm. The Journal of Finance 38,127-140.

Hassan Al-Tamimi, H. A. (2010). Factors influencing performance of the UAE Islamic and conventional national banks. Global Journal of Business Research, 4(2), 1-9

Kasim, S. H., Majid, M. S. A., \& Yusof. R. M. (2009). Impact of monetary policy shocks on the conventional and Islamic banks in a dual banking system: Evidence from Malaysia. Journal of Applied Economics, 30(1), 4158.

Khrawish, A., \& Siam, Z. (2011). Determinants of Islamic banks profitability: Evidence from Jordan. Middle Eastern Finance and Economics Journal, 13, 42 - 57.

Kosmidou, K., F., Pasiouras, \& Tsaklanganos, A. (2007). Domestic and multinational determinants of foreign bank profits: The case of Greek banks operating abroad. Journal of Multinational Financial Management, 17(1), $1-15$.

Micco, A., Ugo, P. \& Monica, Y. (2007). Bank ownership and performance: Does politics matter? Journal of Banking and Finance, 31, 219-241

Miller, S., \& Noulas, A. (1997). Portfolio mix and large-bank profitability in the USA. Applied Economics, 29, 505-12.

Molyneux, P., \& Thornton, J. (1992). Determinants of European bank profitability. Journal of Banking and Finance, 16(6), 1173-1178.

Naceur, S. B., \& Omran, M. (2011). The effects of bank regulations, competition, and financial reforms on banks' performance. Journal of Emerging Markets Review, 12(1), 1-20.

Ongore, V. O. (2011). The relationship between ownership structure and firm performance: An empirical analysis of listed companies in Kenya. African Journal of Business Management, 5(6), 2120.

Rachdi, H. (2013). What determines the profitability of banks during and before the international financial crisis? Evidence from Tunisia. International Journal of Economics, Finance and Management, 2(4).

Trujillo-Ponce, A. (2013). What determines the profitability of banks? Evidence from Spain. Journal of Accounting and Finance, 53(2), 561-586.

Wainaina, G. (2013). Effect of macroeconomic factors on commercial banks lending to agricultural sector in Kenya. MBA Project, University of Nairobi. 


\section{Appendix A}

\section{Model Diagnostics for ROA Regression Models}

Table A1

Cook's Distance

\begin{tabular}{|c|c|c|c|c|c|}
\hline \multirow{2}{*}{ Models } & \multirow{2}{*}{ Mean } & \multirow{2}{*}{ Median } & \multirow{2}{*}{ SD } & \multicolumn{2}{|c|}{ Range } \\
\hline & & & & Min & Max \\
\hline Model 1 & 0.07 & 0.00182 & 0.399 & $4.98 \mathrm{E}-06$ & 3.06 \\
\hline Model 2 & 0.091 & 0.00109 & 0.544 & $2.20 \mathrm{E}-08$ & 4.18 \\
\hline Model 3 & 0.136 & 0.00154 & 0.891 & $3.45 \mathrm{E}-09$ & 6.89 \\
\hline
\end{tabular}

Table A2

Durbin-Watson Testfor Autocorrelation

\begin{tabular}{llll}
\hline Models & Autocorrelation & DW Statistic & P \\
\hline Model 1 & 0.241 & 1.51 & 0.022 \\
Model 2 & 0.255 & 1.49 & 0.014 \\
\hline Model 3 & 0.277 & 1.44 & 0.034 \\
\hline
\end{tabular}

Table A3

Collinearity Statistics

\begin{tabular}{lcccccccc}
\hline & Model 1 & \multicolumn{3}{c}{ Model 2 } & \multicolumn{3}{c}{ Model 3 } \\
\hline & VIF & Tolerance & & VIF & Tolerance & VIF & Tolerance \\
SR & 1.5 & 0.671 & SR & 1.2 & 0.857 & SR & 1 & 0.972 \\
Size & 1.6 & 0.627 & Size & 1.2 & 0.813 & Size & 1 & 0.972 \\
Liquidity & 1.6 & 0.618 & Loan & 1.4 & 0.731 & & & \\
CAR & 1.3 & 0.794 & Deposit & 1.2 & 0.869 & & & \\
Loan & 1.5 & 0.687 & & & & & & \\
Deposit & 1.4 & 0.74 & & & & & & \\
\hline
\end{tabular}

Appendix B

Model Diagnostics for ROE Regression Models

Table B1

Cook's Distance

\begin{tabular}{lccccc}
\hline Models & Mean & Median & SD & Range & Max \\
\hline Model 1 & 0.0801 & 0.00203 & 0.505 & 0.0000011 & $3.91 \mathrm{E}+00$ \\
Model 2 & 0.0988 & 0.00252 & 0.671 & $3.16 \mathrm{E}-07$ & $5.20 \mathrm{E}+00$ \\
Model 3 & 0.114 & 0.00172 & 0.785 & $3.94 \mathrm{E}-07$ & $6.07 \mathrm{E}+00$ \\
\hline
\end{tabular}




\section{Appendix B (Continue)}

Table B2

Durbin-Watson TestforAutocorrelation

\begin{tabular}{lrrr}
\hline Models & Autocorrelation & DW Statistic & P \\
\hline Model 1 & 0.109 & 1.77 & 0.126 \\
Model 2 & 0.0918 & 1.8 & 0.206 \\
Model 3 & 0.132 & 1.73 & 0.186 \\
\hline
\end{tabular}

Table B3

Collinearity Statistics

\begin{tabular}{|c|c|c|c|c|c|c|c|c|}
\hline & \multicolumn{2}{|c|}{ Model 1} & \multicolumn{4}{|c|}{ Model 2} & \multicolumn{2}{|c|}{ Model 3} \\
\hline & VIF & Tolerance & & VIF & Tolerance & & VIF & Tolerance \\
\hline SR & 1.5 & 0.671 & SR & 1.3 & 0.782 & SR & 1.27 & 0.785 \\
\hline Size & 1.6 & 0.627 & Liquidity & 1.3 & 0.787 & Liquidity & 1.23 & 0.814 \\
\hline Liquidity & 1.6 & 0.618 & Loan & 1.2 & 0.87 & Loan & 1.13 & 0.886 \\
\hline CAR & 1.3 & 0.794 & CAR & 1 & 0.958 & & & \\
\hline Deposit & 1.4 & 0.74 & & & & & & \\
\hline Loan & 1.5 & 0.687 & & & & & & \\
\hline
\end{tabular}

